Review Article

\title{
Role of Nuclear Receptors and their Ligands in Human Trophoblast Invasion
}

Thierry Fournier ${ }^{\mathrm{a}, \mathrm{b}}$, Karen Handschuh ${ }^{\mathrm{a}, \mathrm{b}}$, Vassilis Tsatsaris ${ }^{\mathrm{a}, \mathrm{b}, \mathrm{c}}$, Jean Guibourdenche $\mathrm{e}^{\mathrm{a}, \mathrm{b}, \mathrm{d}}$, Danièle Evain-Brion ${ }^{\mathrm{a}, \mathrm{b}}$

${ }^{\text {a } I N S E R M, ~ U 767, ~ P a r i s, ~ F-75006, ~ F r a n c e ~}$

${ }^{\mathrm{b}}$ Université Paris Descartes, Faculté des Sciences Pharmaceutiques et Biologiques, 75006 Paris, France

${ }^{c}$ AP-HP, Hôpital Cochin, Maternité Port-Royal, 75014 Paris, France

d AP-HP, Hôpital Robert-Debré, Biochimie fœto-placentaire, 75019, Paris, France

Corresponding author to whom all correspondence should be addressed: Thierry Fournier, INSERM, U767, Faculté des Sciences Pharmaceutiques et Biologiques, 4 avenue de l’Observatoire, 75006 Paris, France

Tel.: +331537396 03; fax: +33144073992.

E-mail address: Thierry.Fournier@univ-paris5.fr

Key words: preeclampsia; extravillous cytotrophoblast; trophoblast invasion; PPAR $\gamma$; LXRß; oxidized LDLs

Short Title: Oxidized LDLs and trophoblast invasion 


\section{Abstract}

Human implantation involves a major invasion of the uterus wall and a complete remodelling of the uterine arteries by the extravillous cytotrophoblasts (EVCT). Abnormality of these early steps of placental development leads to poor placentation, fetal growth defects and is very often associated with preeclampsia, a major and frequent complication of human pregnancy. To study the mechanisms that control trophoblast invasion during early placental development and to provide new insight in the understanding of preeclampsia, we have developed in vitro models of human invasive trophoblasts. We showed that activation of the ligand-activated nuclear receptor PPAR $\gamma$ with synthetic (rosiglitazone) or natural $\left(15\right.$ deoxyPGJ $\left._{2}\right)$ agonists inhibits the trophoblastic invasion process. Analysis of PPAR $\gamma$-target genes revealed that placental growth hormone and the protease PAPP-A might be involved in the PPAR $\gamma$-mediated effect in an autocrine manner. We next investigated for PPAR $\gamma$ ligands at the maternofetal interface and showed that oxidized-LDLs are present in EVCT in situ and decrease trophoblast invasion in vitro. Analysis of oxidized-LDLs revealed that they contain potent PPAR $\gamma$ agonists such as eicosanoids but also high levels of oxysterols, which are specific ligands for the liver X receptor. The isoform B of LXR was found in EVCT in situ, and activation of LXRß with synthetic or natural ligands inhibits trophoblast invasion in vitro. Together, our data underscore a major role for PPAR $\gamma$ and LXRß in the control of human trophoblast invasion and suggest that excess of ligands such as oxidized-LDLs at the implantation site might contribute to the development of preeclampsia. 


\section{Development of human placenta}

Implantation of the human conceptus involves the invasion of the uterine epithelium and the underlying stroma by extra embryonic trophoblastic cells, which undergo a complex process of proliferation, migration and differentiation. One particularity of human placentation is the very high degree of trophoblast invasion during the first trimester (Aplin, 1991) unparalleled in other mammals. The trophoblasts named extravillous cytotrophoblasts (EVCT) invade the uterine wall and the associated arterioles where they replace the endothelial lining and most of the musculoelastic tissue of the vessel wall. This arteriole remodelling leads to low resistance vessels that provide adequate supply of maternal blood for fetal growth (Loke and King, 1995). The human trophoblastic invasion, unlike tumour invasion, is precisely regulated. It is temporally restricted to early pregnancy and it is spatially confined to the endometrium, the first third of the myometrium and the associated uterine arterioles (Fisher and Damsky, 1993; Redman, 1997). Trophoblast migration and invasive capacity have been shown to be modulated by numerous factors including oxygen concentration (Zhou et al, 1998), transforming growth factor (TGF- $\beta$ ), IGF-II and IGFBP-1 (Irving and Lala, 1995; Hamilton et al, 1998), epidermal growth factor (Bass et al, 1994) and hepatocyte growth factor (Cartwright et al, 1999).

Defective invasion of the uterine spiral arteries is directly involved in preeclampsia, a major and frequent complication of human pregnancy with serious foetal and maternal consequences (for review see Redman et al, 1993). Due to the specificity of the human placenta, no easily accessible animal models are available to study trophoblast invasion and the pathophysiology of preeclampsia. Hence, we have developed two in vitro models to investigate the regulation of human trophoblast differentiation and invasion (Tarrade et al, 2001a and 2001b, Pavan et al, 2003, Handschuh et al, 2006a and 2006b). 


\section{In vitro model of human invasive extravillous cytotrophoblasts (Cf. Figure 1)}

The first model consists of primary cultures of trophoblastic cells isolated by gentle enzymatic digestion from first trimester chorionic villi and purified as previously described (Tarrade et al, 2001a and 2001b, Handschuh et al, 2006a). Cultured on an extra cellular matrix such as Matrigel, these cells are non proliferative and express specific markers of invasive EVCT such as cytokeratin 7 (CK7), human leukocyte antigen-G (HLA-G), human placental lactogen (hPL), the protooncogene c-erbB2, CD9 and the alpha5 subunit of the alpha5-beta1 fibronectin receptor (Tarrade et al, 2001a and 2001b; Pavan et al, 2003). The second model of human invasive trophoblasts was obtained from a primary culture of EVCT transformed with the simian virus 40 large $\mathrm{T}$ antigen. This trophoblastic cell line (HIPEC65) is proliferative and highly invasive when cultured on Matrigel and have been fully characterized (Pavan et al, 2003). HIPEC 65 cells express the CK7, HLA- G and CD9, the three essential antigens considered as EVCT specific markers as established in two workshop reports (King et al, 2000; Shiverick et al, 2001). In addition, markers of invasive trophoblasts including c-erbB2, TGFß2 and alpha5 subunit are also expressed by HIPEC65.

\section{Expression and role of PPAR $\gamma / \mathrm{RXR} \alpha$ heterodimers in early placental development}

The peroxisome proliferator-activated receptor- $\gamma(\operatorname{PPAR} \gamma)$ is a member of the nuclear receptor superfamily that controls the expression of a large array of genes in a liganddependent manner. DNA binding of PPAR $\gamma$ to its response element (composed of a direct repeat of the core hexanucleotide motif AGGTCA with one intervening base named DR1) requires obligate heterodimerization with another nuclear receptor, the retinoid $\mathrm{X}$ receptor (RXR) (for review see Desvergne and Whali, 1999). PPAR $\gamma$ is bound and activated by natural ligands such as eicosanoids, fatty acids and oxidized low-density lipoprotein compounds. 15deoxy-delta $(12,14)$ prostaglandin $\mathbf{J}_{2}\left(15 \mathrm{~d}-\mathrm{PGJ}_{2}\right)$ is considered as a potent natural PPAR $\gamma$ 
agonist (Kliewer et al, 1997; Nagy et al, 1998; Forman et al, 1995). In addition, synthetic agonists of PPAR $\gamma$, such as rosiglitazone that belongs to the thiazolidinedione class of drugs, have been developed and used in the treatment of type 2 diabetes. PPAR $\gamma / \mathrm{RXR}$ heterodimers can be activated by either selective RXR (9-cis retinoic acid) or PPAR $\gamma$ ligands, the combination resulting in an additive or synergistic effect.

In 1999, genetic studies performed in mice established that two nuclear hormone receptors, RXRs, on the one hand, and $\operatorname{PPAR} \gamma$, on the other hand, are essential for placental development and vasculature. Indeed, $\mathrm{RXR} \alpha^{-/-} / \mathrm{RXR} \beta^{-/-}$conceptuses fail to develop a normal chorioallantoic placenta with a functional labyrinthine zone, resulting in compromised maternal-fetal exchanges and therefore in early embryonic death (Wendling et al, 1999). Likewise, PPAR $\gamma^{-/-}$conceptuses exhibited similar placental agenesis with defects in trophoblast differentiation and vascular processes (Barak et al, 1999; Kubota et al, 1999). These studies demonstrated that PPAR $\gamma / \mathrm{RXR}$ heterodimers are essential for implantation and the formation of a functional placenta in mice.

In human placenta, PPAR $\gamma$ is specifically expressed in the villous cytotrophoblast (VCT) and syncytiotrophoblast, as well as in the EVCT along their differentiation pathway, including proliferative and intermediate EVCT in the proximal and distal columns of the anchoring villi, invasive EVCT located in the deciduas, endovascular and perivascular EVCT, and giant cells (for review see Fournier et al, 2006). Therefore, PPAR $\gamma$ may be used as a marker of human trophoblast. By contrast, a pleiotropic expression of the isoform alpha of RXR was found at $\square$ the $\square$ maternofoetal interface RXR $\alpha$ being expressed in trophoblast from villous and extravillous origin, the mesenchymal core of the villi and the different components of the deciduas (Tarrade et al, 2000; Tarrade et al 2001b). Thus, these histological studies demonstrated that at the maternofetal interface, PPAR $\gamma / \mathrm{RXR} \alpha$ heterodimers are exclusively located in the trophoblasts. 
Using the two in vitro models of human invasive trophoblast, we showed that both primary cultures of EVCT and HIPEC65 cells express high levels of PPAR $\gamma$ and RXR $\alpha$, which can be colocalized in the nuclei by immunocytochemistry. Activation of PPAR $\gamma / \mathrm{RXR} \alpha$ heterodimers by either natural $\left(15 \mathrm{~d}-\mathrm{PGJ}_{2}\right)$ or synthetic (rosiglitazone) PPAR $\gamma$ ligands markedly decreased cell invasion in a concentration-dependent manner as assayed in Boyden chambers as illustrated in Figure 2 (Tarrade et al, 2001b; Fournier et al, 2002; Pavan et al, 2003). Interestingly, whereas in numerous cellular models PPAR $\gamma$ activation inhibits both cell proliferation and migration (Grommes et al, 2006; Liu et al, 2005), it did not modify cell growth in HIPEC65 cells suggesting that inhibition of cellular invasiveness by PPAR $\gamma$ agonists without alteration of cell growth might be specific to trophoblastic cells (Pavan et al, 2003).

\section{Mechanisms involved in the inhibition of trophoblast invasion by PPAR $\gamma$}

Cellular invasion requires different steps such as lost of cell-cell adhesion and communication, modification of receptors to the matrix such as integrins, protease activation promoting matrix degradation, cytoskeletal activation and secretion of soluble factors promoting cell migration. We observed that activation of PPAR $\gamma$ by the specific agonist rosiglitazone significantly down regulated gene expressions of the human placental growth hormone (hPGH) and of the pregnancy-associated plasma protein A (PAPP-A) (Handschuh et al, 2006a).

Hormones belonging to the $\mathrm{GH} /$ prolactin family are expressed at the maternofetal interface and are involved in cell motility in various models. We examined the possible regulatory role of hPGH in EVCT invasiveness. First, we found in situ by immunohistochemistry performed on first trimester human placental sections that EVCT expressed both hPGH and human GH receptor (hGHR). Using the Matrigel-coated transwell 
invasion model, we observed strong hPGH and hGHR expression when EVCT invaded Matrigel and moved through the pores of the filter on which they were cultured. Incubation of EVCT with exogenous hPGH stimulated trophoblast invasiveness through activation of the Janus kinase-2/signal transducer and activator of transcription factor-5 signalling pathway (Cf. Figure 3) (Lacroix et al, 2005). These results provide evidence that hPGH participates to the control of trophoblast invasiveness and as a PPAR $\gamma$ target gene, might be involved in the PPAR $\gamma$-mediated inhibition of trophoblast invasion in an autocrine manner.

PAPP-A is a metzincin metalloproteinase that increases in maternal serum during pregnancy. It cleaves the insulin-like growth factor-dependent binding protein-4 (IGFBP-4) and consequently modulates the amount of bioactive IGF-II, a factor known to promote trophoblast invasion. The expression of PAPP-A and its regulation by PPAR $\gamma$ were studied in vitro using primary cultures of invasive extravillous (EVCT) and endocrine villous (VCT) cytotrophoblasts isolated from the same first trimester chorionic villi. First, we demonstrated that invasive EVCT expressed and secreted 10 times more PAPP-A than the endocrine VCT suggesting that PAPP-A might be considered as an early marker of physiological trophoblast invasion. Then, we showed that activation of PPAR $\gamma$ inhibited PAPP-A gene expression and secretion specifically in EVCT, whereas it had no effect in VCT (Cf. Figure 4) (Handschuh et al, 2006a). These results strongly suggest that the PPAR $\gamma$-induced decrease in PAPP-A observed in invasive EVCT might diminish the amount of bioactive IGF-II, a factor that promotes trophoblast invasion.

\section{$\operatorname{PPAR} \gamma$ ligands at the maternofetal interface}

Lipid metabolism is profoundly altered during human pregnancy and it has been reported that LDL, which are involved in the plasma transport of triglycerides, are smaller, denser and more susceptible to oxidation during pregnancy (Winkler et al, 2000; Anber et al, 1996). 
Oxidized metabolites of linoleic acid such as 9- and 13-hydroxy-octadedienoic acid (HODE) are found in oxidized low-density lipoproteins and were identified as PPAR $\gamma$ specific ligands (Nagy et al, 1998). In addition, oxidized lipids including 9S-HODE, 13SHODE, 15S-hydroxy-5Z,11Z,13E-eicosatetraenoic acid (15S-HETE) were shown to activate PPAR $\gamma$ in primary human villous trophoblasts (Schild et al, 2002). We therefore hypothesized that oxidative modification of LDL particles in the blood and/or at the placental bed site might be involved in modulating trophoblast invasion during the early stages of placental development. We assessed the distribution of oxidized LDLs (oxLDL) in sections of first trimester placenta and studied the effect of oxLDL on trophoblast invasion in vitro. We showed by immunohistochemistry that oxLDL were present in cytotrophoblasts of villous and extravillous origin and demonstrated using our in vitro invasion assay that oxLDL, but not native LDL, inhibited trophoblast invasion in a concentration-dependent manner as illustrated in Figure 5A) (Pavan et al, 2004a). Analysis of oxLDL content revealed that only oxLDL containing a high proportion of oxysterols and phosphatidylcholine hydroperoxide derivatives, reduced trophoblast invasion. Phosphatidylcholine hydroperoxide derivatives provide PPAR $\gamma$ ligands such as HETE and HODE, whereas oxysterols such as 7 ketocholesterol provide ligands to another nuclear receptor, the liver X receptor (LXR) that also heterodimerize with RXR. In addition to PPAR $\gamma$ and RXR $\alpha$, the isoform beta of LXR was found in the nuclei of primary EVCT. Finally, we showed that activation of PPAR $\gamma / \mathrm{RXR} \alpha$ or RXR $\alpha / \mathrm{LXR} \beta$ heterodimers with specific natural and synthetic PPAR $\gamma$ or LXR ligands markedly inhibit trophoblast invasion in vitro (Cf. Figure 5B) (Pavan et al, 2004b). The clinical relevance of these in vitro findings was enforced by the coimmunodetection in situ of oxLDLs, the scavenger receptor LOX-1 involved in oxLDL uptake, and the two nuclear receptors PPAR $\gamma$ and LXRß in invasive EVCT at the maternofoetal interface (Cf. Figure 6) (Pavan et al, 2004a). Interestingly, LOX-1 protein 
levels were shown to be increased in preeclamptic placental tissues and a significant higher number of LOX-1 positive syncyciotrophoblast was found in preeclamptic compared to normal placentas (Lee et al, 2005). Despite the absence of data concerning LOX-1 expression in EVCT (the trophoblasts involved in trophoblastic invasion) from preeclamptic placentas, we can speculate that increase number of LOX-1 EVCT might lead to increase oxidizedLDLs uptake and inhibition of trophoblastic invasion contributing therefore to the pathogenesis of preeclampsia.

In conclusion, our results suggest that human trophoblast invasion might be regulated by oxidized LDLs in vivo through activation of the nuclear receptors PPAR $\gamma$ and LXRß, and provide new insights into the pathophysiology of preeclampsia associated with oxidative stress and defective trophoblast invasion. Mechanisms by which oxidized LDLs present at the maternofetal interface might inhibit human trophoblast invasion are illustrated in figure 7.

\section{Acknowledgement}

This work was supported by "la Caisse d'Assurance Maladie des Professions Libérales de Provinces", CAMPLP, 75578 Paris cedex 12, France. The authors wish to thank the staff of the Obstetric Department of hospital Cochin (75014 Paris, France) for assistance with specimen collection. 


\section{References}

Anber V, Griffin BA, McConnell M, Packard CJ, Shepherd J., 1996. Influence of plasma lipid and LDL-subfraction profile on the interaction between low density lipoprotein with human arterial wall proteoglycans. Atherosclerosis, 124, 261-271.

Aplin, J.D.,1991. Implantation, trophoblast differentiation, and haemochorial placentation: mechanistic evidence in vivo and in vitro. J. Cell. Science, 99, 681-692.

Barak Y, Nelson M, Ong ES, et al., 1999. PPAR $\gamma$ is required for placental, cardiac, and adipose tissue development. Mol. Cell., 4, 585-595.

Bass, E., Morrish D., Roth I., Bhardwaj D., Taylor R., Zhou Y. and Fisher S., 1994. Human cytotrophoblast invasion is up-regulated by epidermal growth factor: Evidence that paracrine factors modify this process. Dev. Biol. 164, 550-561.

Cartwright, J., Holden D. and Whitley G., 1999. Hepatocyte growth factor regulates human trophoblast motility and invasion: a role for nitric oxide. Br. Journal of Pharmacology, 128, 181-189.

Desvergne, B. and Wahli W., 1999. Peroxisome proliferator-activated receptors: nuclear control of metabolism. Endocrine Review, 20, 649-688.

Fisher, S.J. and Damsky C.H.,1993. Human cytotrophoblast invasion. Sem. Cell Biol., 4, 183188.

Forman, B.M., Tontonoz P., Chen J., Brun R.P., Spiegelman B.M. and Evans R.M., 1995. 15Deoxy-delta 12, 14-prostaglandin $\mathrm{J} 2$ is a ligand for the adipocyte determination factor PPAR gamma. Cell, 83, 803-812.

Fournier T, Pavan L, Tarrade A, Schoonjans K, Auwerx J, Rochette-Egly C, Evain-Brion D., 2002. The role of PPAR-gamma/RXR-alpha heterodimers in the regulation of human trophoblast invasion. Ann. N. Y. Acad. Sci., 973, 26-30.

Fournier T, Tsatsaris V, Handschuh K, Evain-Brion D., 2006. PPARs and the Placenta. 
Placenta, In Press.

Grommes C, Landreth GE, Sastre M, Beck M, Feinstein DL, Jacobs AH, Schlegel U, Heneka MT, 2006. Inhibition of in vivo glioma growth and invasion by PPARgamma agonist treatment. Mol. Pharmacol., In press.

Hamilton, G., Lysiak J., Han V. and Lala P., 1998. Autocrine-paracrine regulation of human trophoblast invasiveness by insulin-like growth factor (IGF)-II and IGF-binding protein (IGFBP)-1. Exp. Cell Res, 244, 147-156.

Handschuh K, Guibourdenche J, Guesnon M, Laurendeau I, Evain-Brion D, Fournier T., 2006a. Modulation of PAPP-A expression by PPARgamma in human first trimester trophoblast. Placenta, Suppl A:S127-134.

Handschuh K, Guibourdenche J, Tsatsaris V, Guesnon M, Laurendeau I, Evain-Brion D, Fournier T., 2006b. Human Chorionic Gonadotropin Expression in Human Trophoblasts from Early Placenta: Comparative Study Between Villous and Extravillous Trophoblastic Cells. Placenta, In press.

Irving, J. and Lala P., 1995. Functional role of cell surface integrins on human trophoblast cell migration: regulation by TGF- beta , IGF-II, and IGFBP-1. Exp. Cell. Res. 217, 419-427.

King, A., Thomas L. and Bischof P., 2000. Cell Culture Models of Trophoblast II: Trophoblast Cell Lines - A Workshop Report. Placenta, suppl A, S113-119.

Kliewer, S.A., Sundseth S.S., Jones S.A., Brown P.J., Wisely G.B., Koble C.S., Devchand P., Wahli W., Willson T.M., Lenhard J.M. and Lehmann J.M., 1997. Fatty acids and eicosanoids regulate gene expression through direct interactions with peroxisome proliferator-activated receptors alpha and gamma. Proc. Natl. Acad. Sci. U S A, 94, 43184323.

Kubota N, Terauchi Y, Miki H, et al., 1999. PPAR gamma mediates high-fat diet-induced adipocyte hypertrophy and insulin resistance. Mol. Cell., 4,597-609. 
Lacroix MC, Guibourdenche J, Fournier T, Laurendeau I, Igout A, Goffin V, Pantel J, Tsatsaris V, Evain-Brion D., 2005. Stimulation of human trophoblast invasion by placental growth hormone. Endocrinology, 146, 2434-2444.

Lee H, Park H, Kim YJ, Kim HJ, Ahn YM, Park B, Park JH, Lee BE., 2005. Expression of lectin-like oxidized low-density lipoprotein receptor-1 (LOX-1) in human preeclamptic placenta: possible implications in the process of trophoblast apoptosis.

Placenta 26,226-33.

Liu J, Lu H, Huang R, Lin D, Wu X, Lin Q, Wu X, Zheng J, Pan X, Peng J, Song Y, Zhang M, Hou M, Chen F., 2005. Peroxisome proliferator activated receptor-gamma ligands induced cell growth inhibition and its influence on matrix metalloproteinase activity in human myeloid leukemia cells. Cancer Chemother. Pharmacol., 56, 400-408.

Loke, Y.W. and King A., 1995. (Cambridge university press edn), Cambridge : Cambridge University press.

Nagy, L., Tontonoz P., Alvarez J.G., Chen H. and Evans R.M., 1998. Oxidized LDL regulates macrophage gene expression through ligand activation of PPARgamma. Cell, 93, 229-240.

Pavan L, Tarrade A, Hermouet A, Delouis C, Titeux M, Vidaud M, Therond P, Evain-Brion D, Fournier T., 2003. Human invasive trophoblasts transformed with simian virus 40 provide a new tool to study the role of PPARgamma in cell invasion process. Carcinogenesis, 24, 1325-1236.

Pavan L, Tsatsaris V, Hermouet A, Therond P, Evain-Brion D, Fournier T., 2004a. Oxidized low-density lipoproteins inhibit trophoblastic cell invasion. J. Clin. Endocrinol. Metab. 89, 1969-1972.

Pavan L, Hermouet A, Tsatsaris V, Therond P, Sawamura T, Evain-Brion D, Fournier T., 2004b. Lipids from oxidized low-density lipoprotein modulate human trophoblast invasion: involvement of nuclear liver X receptors. Endocrinology, 145, 4583-4591. 
Redman, C., Sargent, I., Starkey, P., 1993. The human placenta. Blackwell: Oxford; 433-467.

Redman, C., 1997. Cytotrophoblasts: masters of disguise. Nat. Med., 3, 610-611.

Schild RL, Schaiff WT, Carlson MG, Cronbach EJ, Nelson DM, Sadovsky Y., 2002. The activity of PPAR gamma in primary human trophoblasts is enhanced by oxidized lipids. J. Clin. Endocrinol. Metab., 87, 1105-1110.

Shiverick, K.T., King A., Frank H.-G., Whitley G.S.J., Cartwright J.E. and Schneider H., 2001. Cell Culture Models of Human Trophoblast II: Trophoblast Cell Lines - A Workshop Report. Placenta, suppl A, S104-S106.

Tarrade A, Rochette-Egly C, Guibourdenche J, Evain-Brion D., 2000. The expression of nuclear retinoid receptors in human implantation. Placenta, 21, 703-710.

Tarrade A, Lai Kuen R, Malassine A, Tricottet V, Blain P, Vidaud M, Evain-Brion D., 2001a. Characterization of human villous and extravillous trophoblasts isolated from first trimester placenta. Lab. Invest., 81, 1199-1211.

Tarrade, A., Schoonjans K., Pavan L., Auwerx J., Rochette-Egly C., Evain-Brion D. and Fournier T., 2001b. PPARgamma/RXRalpha heterodimers control human trophoblast invasion. J. Clin. Endocrinol. Metab. 86, 5017-5024.

Wendling O, Chambon P, Mark M., 1999. Retinoid X receptors are essential for early mouse development and placentogenesis. Proc. Natl. Acad. Sci., 96, 547-551.

Winkler K, Wetzka B, Hoffmann MM, Friedrich I, Kinner M, Baumstark MW, Wieland H, et al., 2000. Low density lipoprotein (LDL) subfractions during pregnancy: accumulation of buoyant LDL with advancing gestation. J. Clin. Endocrinol. Metab., 85, 4543-4550.

Zhou, Y., Genbacev O., Damsky C.H. and Fisher S.J., 1998. Oxygen regulates human cytotrophoblast differentiation and invasion: implications for endovascular invasion in normal pregnancy and in pre-eclampsia. J. Reprod. Immunol. 39, 197-213. 


\section{Figure legends}

\section{Figure 1. In vitro models for studying human trophoblast invasion}

Human extravillous cytotrophoblasts (EVCT) isolated from first trimester anchoring villi are immunostained using anti-cytokeratin 7 antibodies and nuclei counter stained with Dapi. The cell line HIPEC65 was obtained by transformation of primary EVCT with SV40 T/t antigens. For invasion assay, primary EVCT or HIPEC65 were cultured on Matrigel-coated transwell. Cells invaded the Matrigel and cross the $8 \mu \mathrm{m}$ diameter pores of the membrane as illustrated by scanning electron microscopy. Pseudopodia and cells crossing the porous membrane were quantified and normalized to the number of nuclei after immunostaining with anti-CK7 antibody and counter stained with Dapi.

\section{Figure 2. Expression and role of PPAR $\gamma$ and RXR $\alpha$ in primary EVCT and HIPEC65} cells.

Upper panel: Immunolocalization of PPAR $\gamma$ and $\mathrm{RXR} \alpha$ in the nuclei of ECVT after $48 \mathrm{~h}$ of culture on Matrigel and in HIPEC65 cells. No staining was observed when incubated with non-immune antibodies (IgG).

Lower panel: EVCT were cultured on matrigel-coated transwells for $48 \mathrm{~h}$ and invasion was quantified as described in Figure 1. Results are expressed as number of pseudopodes per number of nuclei relative to control. EVCT were incubated with increasing concentrations of rosiglitazone or d15-PGJ $\mathrm{J}_{2}$. Results represent the mean $\pm \mathrm{SD}$ of at least 3 different cultures. * $\mathrm{p}<0.05$ treated vs control. 
Figure 3. Human PGH increased trophoblast invasion through activation of the Jak/STAT pathway.

Left panel: EVCT were grown on Matrigel-coated transwell for $72 \mathrm{~h}$ in the presence or absence of increasing concentrations of hPGH.

Right panel : EVCT were cultured for $72 \mathrm{~h}$ in the absence (control) or presence of hPGH (20ng/ml), the Jak inhibitor AG490 $(10 \mu \mathrm{M})$, or hPGH $(20 \mathrm{ng} / \mathrm{ml})$ plus AG490 $(10 \mu \mathrm{M})$. AG490 inhibited the effect of hPGH on the invasion index. Values are the mean \pm SEM of duplicate determinations for at least four independent cultures from different placentas. ${ }^{*}, P$ $<0.05 ; * *, P<0.001$.

Figure 4. Comparative expression of PAPP-A in human cultured VCT and EVCT and regulation by PPAR $\gamma$.

Upper panel: Supernatants from 24, 48 and $72 \mathrm{~h}$ cultured VCT and EVCT were collected and PAPP-A quantified. Protein secretions were expressed as UI/L and normalized to DNA content for comparison between VCT and EVCT. Values represent the mean \pm SEM of three independent cultures obtained from three different placentas. EVCT vs VCT: $* \mathrm{P}<0.05 ; * * \mathrm{P}$ $<0.01 ; * * * \mathrm{P}<0.001$

Lower panel: PAPP-A secreted protein were measured in $48 \mathrm{~h}$-cultured human EVCT or VCT treated or not with $1 \mu \mathrm{M}$ of the PPAR $\gamma$ agonist rosiglitazone. Values were expressed relative to untreated cells and represent the mean \pm SEM. For protein determination, six independent cultures from six different placentas were run in duplicate. Treated vs control: * $\mathrm{P}<0.05$

\section{Figure 5. Effects of oxidized LDLs and their ligands on EVCT invasion in vitro}

Upper panel: Extravillous cytotrophoblast were cultured in Matrigel-coated Transwells, incubated with increasing concentrations of native or copper-oxidised LDL for $48 \mathrm{~h}$ and 
trophoblastic cell invasion quantified as previously described. Results represent the mean \pm SEM of three independent cultures obtained from individual placentas run in triplicate. $* \mathrm{P}<$ 0.05 , treated vs. controls

Middle panel: Schematic representation of a low-density lipoprotein and their components that provide potential ligands for PPAR $\gamma$ and/or LXR after oxidation.

Bottom panel: Effects of natural ligands (plain) and synthetic agonists (hatched) of PPAR $\gamma$ (brown) and LXR (yellow) on trophoblast invasion in vitro. Cells were incubated for $48 \mathrm{~h}$ with 9-HODE $(3 \mu \mathrm{M}), 13$-HODE $(3 \mu \mathrm{M}), 15$-HETE $(3 \mu \mathrm{M}), 15$ d-PGJ $_{2}(10 \mu \mathrm{M})$, Rosiglitazone $(1 \mu \mathrm{M})$, 7-ketocholesterol (7-ketoCH; 1 $\left.\mu \mathrm{g} . \mathrm{L}^{-1}\right)$ and the LXR agonist T0901317 $(5 \mu \mathrm{M})$ and invasion assays were performed as described. Values represent the mean \pm SEM of three independent cultures obtained from individual placentas and run in triplicate. $* \mathrm{P}<0.05$, treated vs. controls.

Figure 6. Colocalisation in EVCT in situ of oxidized LDLs, LOX-1, PPAR $\gamma$ and LXRß. Immunohistochemistry was performed on first trimester human placental sections. First trimester placental samples from legal first trimester abortion were obtained after informed consent of the patient. Placental sections were fixed in $4 \%$ formalin and then embedded in paraffin. Cytokeratin 7 (CK07) staining is specific of trophoblasts from extravillous (EVCT) or villous (VCT and ST) origin. OxLDL, the scavenger receptor LOX-1 involved in OxLDL uptake, PPAR $\gamma$ and LXRß nuclear receptors were colocalized in EVCT. No staining is observed in control sections incubated with non-immune IgG. SC: stromal core.

Figure 7. Schematic illustration of the hypothetical mechanisms involved in oxidized LDL-mediated inhibition of human trophoblast invasion.

1) LOX-1-mediated uptake of oxidized LDLs present at the maternofetal interface; 2) release 
of potential ligands for PPAR $\gamma$ and LXR nuclear receptors (RN); 3) trans-repression of genes coding for factors involved in trophoblastic invasion such as hPGH or PAPP-A, a protease that cleaves IGF-BP4; 4) inhibition of hPGH synthesis and secretion and decrease in IGF-II availability; 5) two soluble factors that promote trophoblastic invasion in an autocrine/paracrine fashion. 